\title{
Pattern and seasonal variations in death due to electrocution: A retrospective study
}

\author{
Akhilesh K Pathak ${ }^{1}$, NL Disania ${ }^{2}$ \\ ${ }^{1}$ Department of Forensic Medicine and Toxicology, Medical College Baroda, Vadodara, Gujarat, India. \\ ${ }^{2}$ Department of Forensic Medicine and Toxicology, Sawai Man Singh Medical College, Jaipur, Rajasthan, India. \\ Correspondence to: Akhilesh K Pathak, E-mail: dr.akhilesh_pathak@yahoo.co.in \\ Received September 12, 2014. Accepted September 22, 2014
}

\section{Abstract}

Background: Owing to extensive use of electricity in home and industries, electrocution injuries are one of the common causes of morbidity and mortality in India. Deaths due to fatal electric injuries are quite common in Rajasthan, and hence a retrospective study was conducted on the cases of death due to electrocution.

Objectives: This study was carried out with the aim to find out the pattern and seasonal variations, and to discuss the medicolegal aspects of fatal electrocution.

Materials and Methods: This retrospective study was conducted at Swai Man Singh Hospital, Jaipur, Rajasthan, India. Total 3123 autopsies were conducted in the Department of Forensic Medicine and Toxicology during 2012; of them, 80 cases of death due to electrocution were analyzed.

Results: In this study, majority of the victims were men (85\%) aged between 20 and 50 years (75\%). In $70 \%$ cases, victims were electrocuted at home and all cases (100\%) were accidental in nature. In most of the victims, upper limbs (51.2\%) were involved due to a contact with electric source followed by the cases where the body was showing signs of flame burns $(65.0 \%)$ due to leaping of spark over the body. In this study, we observed that the incidences were typically higher in monsoon season (47.5\%) as compared to other seasons, which shows that there is a characteristic seasonal variation in cases of electrocution. In $40 \%$ cases, the victims were brought dead.

Conclusion: Electric injury varies from nil to severe destruction of tissues, so in all cases of death due to electrocution meticulous autopsy should be performed to help the investigations for the purpose of compensation and to plan future safety measures. Pattern of fatal electrocution injuries in this study is more or less similar to that observed in most of the other studies conducted by various authors and the incidences are typically higher in the rainy season.

KEY WORDS: Electrocution, burns, accidental death, injury

\section{Introduction}

Injuries due to electrocution are a significant contributor to morbidity and mortality throughout the world. Cases of electric injury or death due to electrocution are quite common in India where the people are electrocuted commonly due to inadvertent touching of current source and rarely by electric flasharc leaping on them from a low-voltage domestic supply or rarely when they had come in the magnetic field of a hightension electric supply. The main effect of electricity is shock

\begin{tabular}{|l|l|}
\hline Website: http://wnw.jimsph.com & Access this article online \\
\hline DOI: 10.5455/ijmsph.2015.120920146 & \\
\hline
\end{tabular}

produced by its current and the injuries due to electrocution depend on many factors such as voltage and frequency of current, duration of contact with body, atmospheric conditions, and route of current in the body. ${ }^{[1]}$ Though the human body is a bad conductor of electric current but the wetness of skin or ground increases the chances of electrocution, which is commonly observed in rainy seasons.

Pattern of injuries due to electrocution in Rajasthan has not been studied before this study. Though the incidences of death due to electrocution are less, but the cases of injuries are quite common due to accidental touching of a current source, which is also concluded by most of the authors in their studies in India. ${ }^{[2-4]}$ The rising incidences of electrocution injuries with the high prevalence in a particular season in the area of Jaipur, Rajasthan, has prompted us to undertake this study to know the epidemiological aspects, pattern of injuries, and other significant medicolegal issues in cases of death due to electrocution and to compare it with the observations of various authors by scientific discussion. 
Table 1: Distribution of electric injury according to age and gender

\begin{tabular}{llcl}
\hline Age group (years) & \multicolumn{1}{c}{ Male } & Female & \multicolumn{1}{c}{ Total } \\
\hline$<10$ & $00(00 \%)$ & $00(00 \%)$ & $00(00 \%)$ \\
$11-20$ & $09(11.2 \%)$ & $01(1.2 \%)$ & $10(12.4 \%)$ \\
$21-30$ & $29(36.2 \%)$ & $02(2.5 \%)$ & $31(38.7 \%)$ \\
$31-40$ & $13(16.2 \%)$ & $03(3.7 \%)$ & $16(20.0 \%)$ \\
$41-50$ & $10(12.4 \%)$ & $03(3.7 \%)$ & $13(16.2 \%)$ \\
$51-60$ & $07(8.7 \%)$ & $03(3.7 \%)$ & $10(12.4 \%)$ \\
Total & $68(85.0 \%)$ & $12(15.0 \%)$ & $80(100 \%)$ \\
\hline
\end{tabular}

Table 2: Seasonal and diurnal variations in cases of electric injury

\begin{tabular}{lccc}
\hline $\begin{array}{l}\text { Month of } \\
\text { incidence }\end{array}$ & $\begin{array}{c}\text { During } \\
\text { Daytime } \\
\text { (7 AM to 7 PM) }\end{array}$ & $\begin{array}{c}\text { During } \\
\text { Nighttime }\end{array}$ & Total \\
(7 PM to 7 AM) & \\
\hline January-March & $12(15.0 \%)$ & $03(3.75 \%)$ & $15(18.7 \%)$ \\
April-June & $08(10.0 \%)$ & $07(8.7 \%)$ & $15(18.7 \%)$ \\
July-September & $26(32.5 \%)$ & $12(15.0 \%)$ & $38(47.5 \%)$ \\
$\begin{array}{l}\text { October- } \\
\quad \text { December }\end{array}$ & $10(12.5 \%)$ & $02(2.5 \%)$ & $12(15.0 \%)$ \\
Total & $56(70.0 \%)$ & $24(30.0 \%)$ & $80(100 \%)$ \\
\hline
\end{tabular}

Table 3: Distribution of cases according to place of incidence

\begin{tabular}{lcclc}
\hline $\begin{array}{l}\text { Place of } \\
\text { electric } \\
\text { injury }\end{array}$ & Home & $\begin{array}{c}\text { Working } \\
\text { place }\end{array}$ & Other & Total \\
\hline $\begin{array}{c}\text { Number of } \\
\text { cases (\%) }\end{array}$ & $56(70.0 \%)$ & $14(17.5 \%)$ & $10(12.4 \%)$ & $80(100 \%)$ \\
\hline
\end{tabular}

Table 4: Distribution of cases according to body part involved

\begin{tabular}{lccccc}
\hline Part of body & $\begin{array}{c}\text { Head and } \\
\text { Neck }\end{array}$ & $\begin{array}{c}\text { Upper } \\
\text { limbs }\end{array}$ & $\begin{array}{c}\text { Lower } \\
\text { limbs }\end{array}$ & Trunk & $\begin{array}{c}\text { Whole } \\
\text { body }\end{array}$ \\
\hline $\begin{array}{l}\text { Number of } \\
\text { cases }(\%)\end{array}$ & 07 & 41 & 31 & 17 & 25 \\
\hline
\end{tabular}

Table 5: Distribution of cases according to types of electric injury

\begin{tabular}{lcc}
\hline Types of electric injury & Contact wound & Flame burn \\
\hline Number of cases (\%) & $41(51.2 \%)$ & $52(65.0 \%)$ \\
\hline
\end{tabular}

Table 6: Distribution of cases according to time of survival

\begin{tabular}{lcccccc}
\hline $\begin{array}{l}\text { Time of } \\
\text { survival }\end{array}$ & $\begin{array}{c}\text { Brought in } \begin{array}{c}< \\
\text { dead }\end{array} \\
\text { Day }\end{array}$ & $\begin{array}{c}\mathbf{1 - 3} \\
\text { Days }\end{array}$ & $\begin{array}{c}\mathbf{3 - 7} \\
\text { Days }\end{array}$ & $\begin{array}{c}\geqslant \mathbf{7} \\
\text { Days }\end{array}$ & Total \\
\hline $\begin{array}{c}\text { Number of } \\
\text { cases }(\%)\end{array}$ & 32 & 09 & 11 & 15 & 13 & 80 \\
\hline
\end{tabular}

Table 7: Distribution of electric injury according to its manner

\begin{tabular}{lcccc}
\hline $\begin{array}{l}\text { Manner of } \\
\text { death }\end{array}$ & Accidental & Suicidal & Homicidal & Total \\
\hline $\begin{array}{l}\text { Number of } \\
\text { cases (\%) }\end{array}$ & $80(100 \%)$ & $00(00 \%)$ & $00(00 \%)$ & $80(100 \%)$ \\
\hline
\end{tabular}

\section{Materials and Methods}

This retrospective study was conducted in the Department of Forensic Medicine and Toxicology of Swai Man Singh Hospital, Jaipur, Rajasthan, India. Total 3123 autopsies were conducted from January 1, 2012 to December 31, 2012, and of them, 80 cases $(2.56 \%)$ in which death was alleged due to fatal electrocution were selected for this study. All these cases were studied irrespective of their age and gender, and we also tried to find out the seasonal and diurnal variations, if any, in cases of electrocution. Detailed and complete autopsy examination was conducted with the aim to find the area of body parts affected and types of electric injury, whether it is a contact injury or flash burns due to a spark. Information regarding the incidence of electrocution was collected from the police papers, and autopsy reports were taken into consideration to conclude the manner of death, whether it was suicidal, accidental, or homicidal in nature. Finally, the data were collected and analyzed after comparing with those of Indian and foreign authors.

\section{Results}

We analyzed 80 cases of fatal electric injury, which were brought to us for the autopsy examination during 2012. Majority of the victims were men (85\%) as compared to women, with a male/female ratio of $5.67: 1$. Most of the victims $(38.7 \%)$ were in the third decade of their life, while around three-fourths belonged to younger and adult age groups (e.g., from 21 to 50 years). In our study, no victim of fatal electrocution was found below the age of 10 years. We tried to find out the seasonal and diurnal variations in cases of death due to electrocution, and we observed a characteristic seasonal variation. In this study, incidences of death due electric injury were typically higher in the season of monsoon, which was in the months of July to September in Jaipur, Rajasthan, in 2012. Majority of the incidences (70\%) happened during the daytime between $7 \mathrm{AM}$ and $7 \mathrm{PM}$ as compared to night. In most of the incidences, victims were injured by electrocution when they were at home (70\%) and working with some electric source. Upper limbs were the most common body part affected by electrocution in more than half $(51.2 \%)$ of the cases and contact wound of electrocution was also noticed. Flame burns due to spark of current over the whole body areas with burning of clothes were noticed in $65 \%$ cases, followed by contact injury in $51.2 \%$. In this study, there were some cases in which flame burns were present along 
with contact wound of electrocution. Majority of the victims $(40 \%)$ were brought dead to casualty department followed by the cases who died after 1 day of survival in hospital. In our study, all cases of fatal electric injuries were accidental in nature, and we did not find any case of suicidal or homicidal electrocution.

\section{Discussion}

In India, majority of the cases of electrocution are caused by the low-voltage domestic supply, but those due to hightension supply are also common nowadays. In this study, we analyzed the cases of fatal electrocution in contrast to age, gender, place of incidence with seasonal variations, and type and manner of electrical injury, and the findings were compared with the observations made by other authors. The incidences of death due to fatal electric injuries in our study were $2.56 \%$, which is almost similar with the incidences observed by Gupta et al. ${ }^{[4]}(2.02 \%)$ and Rautji et al. ${ }^{[5]}(1.98 \%)$ in their studies. Incidences of death due to fatal electrocution were quite lower in the studies conducted by the foreign authors ${ }^{[6,7]}$ than those reported by us. In this study, majority of the victims were men (85\%) of adult age group [e.g., from 21 to 50 years $(75 \%)]$, which is consistent with the findings of most of the other authors. ${ }^{[4-8]}$ We made an effort to analyze the cases according to seasonal and diurnal variations and observed a characteristic higher incidences of fatal electrocution in the season of monsoon, which is in the months of July to September in this area. These results were consistent with the observations made by Gupta et al. ${ }^{[4]}$ and Kumar et al. ${ }^{[9]}$, whereas Shaha and Joe ${ }^{[10]}$ and Sheikhazadi et al. ${ }^{[11]}$ found higher incidences of fatal electrocution in summer seasons. The wetness of the environment in rainy season is responsible for the increased incidences. In our study, majority of the incidences $(70 \%)$ happened during the daytime between $7 \mathrm{AM}$ and $7 \mathrm{PM}$ as compared to night.

Most of the victims were electrocuted at homes (70\%) while they were working with some electric source, which was also observed by the other authors in their studies. ${ }^{[4,10]}$ However, Kumar et al. ${ }^{[9]}$ and Sheikhazadi et al. ${ }^{[11]}$ observed higher incidences of fatal electrocution at working places. Our study shows that in majority of the cases upper limbs were the most common body part affected followed by lower limbs, which is similar to the observations of almost all other Indian authors. ${ }^{[4,5,8,9,11]}$ In this study, contact injuries by electrocution were noticed in $51.2 \%$ cases and flame burns due to leaping of spark on the body of victims were observed in $65 \%$ cases. Gupta et al. ${ }^{[4]}$ found contact wounds in $67 \%$ cases and flame burns in $10.5 \%$ cases, whereas Shrigirwar et al. ${ }^{[8]}$ observed contact wounds in $45.3 \%$ cases and flame burns in $9.3 \%$ cases. $^{[4,5]}$ In this study, we have not seen any case where either contact wound of electrocution or flame burns due to spark were seen over the body, as reported by others. ${ }^{[4,5,10,11]}$ It might be because of different geographical and climatic conditions in those areas with disparity in the occurrence of incidence. In majority of the cases, victims were in a state of suspended animation after the incidence where the mortality rate can be decreased effectively by offering them immediate and adequate resuscitation measures. Distribution of cases according to time of survival shows that most of the victims $(40 \%)$ were brought dead in casualty followed by the death of the victim after survival for few days (ranging from 1 to 7 days or more) in hospital. Manner of death in this study was concluded with the help of alleged history regarding the incidence, information from police papers, and findings of autopsy report, and we found that all deaths in our study were accidental in manner and there was no case of death due to suicidal or homicidal electrocution. Almost similar types of findings were observed by other authors in their studies. ${ }^{[4,5,11]}$ Gupta et al. ${ }^{[4]}$ found only one case of suicide whereas Sheikhazadi et al..$^{[11]}$ reported $3.4 \%$ cases of suicide.

\section{Strength}

Strength of our study is that we have laid stress on the parameters such as seasonal and diurnal variations in cases of death due to electrocution. Also, no such study has been conducted so far in Rajasthan on this particular subject. In this study, we had a good sample size in one year, which is not there in the studies of most of the other authors and might be due to low incidences of the cases of death due to electrocution in their area.

\section{Limitations}

There are some limitations also of our study. First, we have studied the cases retrospectively so have to rely on the observations seen by the others, which may vary from person to person. Second, if this study were done prospectively then we could have discovered and analyzed some more issues related with this topic.

\section{Conclusion}

The passage of electric current through human body can produce multiple effects, varying from a localized muscle spasm to sudden death of the person. All cases of death due to electrocution should be investigated properly for the purpose of compensation and future safety measures. Autopsy in cases of death due to electrocution is not an easy task for the autopsy surgeon because injuries over the body vary from nil to gross destruction of tissues. Majority of the fatal injuries are due to inadvertent contact with a low-voltage domestic supply but these may also occur due to working with a faulty line or in industries or rarely when the people come into the area of magnetic field of a high-tension cable. The mortality rate in cases of fatal electrocution can be decreased by the immediate and adequate resuscitation because often the victim may be in a state of suspended animation. In all these cases, history regarding the incidence with detailed examination of scene of crime and autopsy report may help us to conclude the cause of death and its manner so the data can 
be used further to plan and implement the preventive policies to reduce such incidences.

Pattern of fatal electrocution injuries in this study is more or less similar to that observed in most of the other studies conducted by various authors. Our study revealed that the most of the victims were men aged between 20 and 50 years who died at home due to accidental contact electrical injury over limbs. This study also shows a typical seasonal and diurnal variation, according to which the incidences of electrocution were typically higher in the season of monsoon as compared to other seasons.

\section{References}

1. Modi JP In: A Textbook of Medical Jurisprudence and Toxicology, Kannan K, Mathiharan K (Eds.), 24th ed. Nagpur, India: LexisNexis Butterworths Wadhwa, 2012. pp. 494-96.

2. Reddy KSN, Murty OP. The Essentials of Forensic Medicine and Toxicology, 32nd ed. Hyderabad, India: K Sugna Devi, 2013. pp. 130-2.

3. Vij K. Textbook of Forensic Medicine and Toxicology, 5th ed. New Delhi, India: Elsevier, 2011. pp. 179-80.

4. Gupta BD, Mehta RA, Trangadia MM. Profile of deaths due to electrocution: A retrospective study. J Indian Acad Forensic Med 2012;34(1):13-15.
5. Rautji R, Rudra A, Behra C, Dogra TD. Electrocution in south Delhi: A retrospective study. Med Sci Law 2003;(43):350-2.

6. Dokov WDokov W. Forensic characteristics of suicide by electrocution in Bulgaria. J Forensic Sci 2009;54(3):669-71.

7. Laupland KB, Kortbeek JB, Findlay C, Kirkpatrick AW, Hameed SM. Population based study of severe trauma due to electrocution in the Calgary Health Region 1996-2002. Can J Surg 2005;48(4):289-92.

8. Shrigirwar M, Bardake R, Dixit PG. Electrocution: A six year study of electrical fatalities, J Indian Acad Forensic Med 2007; 29(2):50-3.

9. Kumar S, Verma AK, Singh US. Electrocution-related mortality in northern India: A 5 year retrospective study. Egyptian J Forensic Sci 2014;4(1):1-6.

10. Shaha KK, Joe AE. Electrocution-related mortality: a retrospective review of 118 death in Coimbatore, India between January 2002 and December 2006. Med Sci Law 2010;50(2):72-4.

11. Sheikhazadi A, Kiani M, Ghadyani MH. Electrocution-related mortality: a survey of 295 deaths in Tehran, Iran between 2002 and 2006. Am J Forensic Med Pathol 2010;31(1):42-5.

How to cite this article: Pathak AK, Disania NL. Pattern and seasonal variations in death due to electrocution: A retrospective study Int J Med Sci Public Health 2015;4:19-22

Source of Support: Nil, Conflict of Interest: None declared. 